\title{
ASPECTS OF THE OPERATION OF INNOVATIVE COMPANIES ON THE EXAMPLE OF EASTERN POLAND
}

\author{
ASPEKTY FUNKCJONOWANIA INNOWACYJNYCH PRZEDSIĘBIORSTW \\ NA PRZYKŁADZIE POLSKI WSCHODNIEJ
}

https://doi.org/10.34739/zn.2021.55.02

Iwona Koza

Poland, State School of Higher Education in Chełm, Institute of Neophilology ikoza@pwsz.chelm.pl, ORCID: 0000-0002-7299-7159

\begin{abstract}
Innovativeness has been the subject of numerous studies in which researchers look for its conditions, causes and effects. The innovation process begins even before the commencement of scientific research in the enterprise, at the stage of creating an idea, and ends with the implementation of innovation and its dissemination. It is better to construct a wide range of indicators relating to the conditions or the determinants of functioning of innovative companies, including issues, such as, entrepreneurship, technological development and diversity. Particularly interesting can be a specification of these aspects in relation to Eastern Poland - a region with unfavorable conditions for business development because of insufficiently developed economic base, as well as underdevelopment of transport, economic and human resources infrastructure and local market.

Keywords: innovativeness, entrepreneurship, technological development, diversity, Eastern Poland

Streszczenie: Innowacyjność to przedmiot licznych badań, w których badacze doszukują się jej warunków, przyczyn i skutków. Proces innowacji zaczyna się jeszcze przed rozpoczęciem badań naukowych w przedsiębiorstwie, na etapie tworzenia pomysłu i kończy się na wdrożeniu innowacji i jego upowszechnieniu. Warto skonstruować szeroki wachlarz wskaźników odnoszących się do warunków czy determinant funkcjonowania innowacyjnych przedsiębiorstw, w tym do takich zagadnień jak przedsiębiorczość, rozwój technologiczny czy różnorodność. Szczególnie interesujące może być uszczegółowienie wymienionych aspektów w odniesieniu do Polski Wschodniej - regionu o niesprzyjających warunkach dla rozwoju przedsiębiorczości z powodu niedostatecznie rozwiniętej bazy ekonomicznej, a także niedostatków w rozwoju infrastruktury komunikacyjnej, ekonomicznej, zasobów ludzkich oraz lokalnego rynku.
\end{abstract}

Słowa kluczowe: innowacyjność, przedsiębiorczość, rozwój technologiczny, różnorodność, Polska Wschodnia

\section{Introduction}

Innovativeness has been the subject of numerous studies in which researchers look for its conditions, causes and effects. Entrepreneurs treat innovativeness as a means to increase efficiencyand competitiveness or reduce costs. Innovativeness helps to promote the image of enterprises and strengthen the brand, it shows the ability to generate and introduce new organizational, marketing, service and product solutions to the market.

Innovativeness is the basis for gaining a competitive advantage by enterprises and influences their success, which is reflected in their sustainable development.
In recent years, many scientific studies on innovativeness in the fields of economics, sociology, psychology and other social sciences have been performed, creating the basis for reflections on innovativeness carried out in management sciences. In the past, the concept of innovativeness evolved not only with the development of research on innovation and innovativeness but also with the comprehensive, multifaceted development of the world economy.

On the basis of a review of the literature, the following criteria for the division of innovations are distinguished: the subject of innovation, place of implementation and the scope of impact, the scope and degree of novelty, results, benefits, scale of changes, measures leading to innovation, 
character, degree of originality, degree of complexity, method of investing, relation to the natural environment, the source of the creation and the participants of the innovation process.

The emergence of innovation requires deliberate actions that can be named by the term of the innovation process. The process of innovation consists of phases and stages that are chronologically related. There are two main stages in this process - the process of creating innovation and the process of dissemination.

In this article, I would like to explore the conditions and determinants of the functioning of innovative enterprises.

The paragraphs relating to the innovations themselves and the methods of research, especially the conditions for the functioning of innovative enterprises, such as, entrepreneurship, technological development or diversity, will be of a general theoretical nature. The final paragraphs of the article will be devoted to the above-mentioned aspects, presented in a detailed manner in relation to Eastern Poland.

\section{Methodology of enterprise innovativeness research}

In the light of the available research, innovativeness, manifested in an ability to create and implement innovations, is regarded as one of the most important elements of a company's modernity and effectiveness in the market. Factors enabling the gaining of a competitive advantage are access to strategic resources, which in addition to extremely important financial resources include human resources and intellectual capital, but also the ability of the enterprise to create innovations. These abilities depend on leadership, an atmosphere of trust and knowledge management.

According to the Oslo Manual (https://ec.europa.eu/eurostat/web/products-manuals-and-guidelines//OSLO?inheritRedirect=true) developed by the European Commission and the Organization for Economic Cooperation and Development, there are two approaches to collecting data on innovativeness: the entity approach, i.e. the quantitative study of innovativeness in the enterprise, which is the foundation for comparison of companies in different areas of their innovative activity, as well as the subject-related approach, i.e. collecting descriptive, quantitative and qualitative information about specific innovations carried out in individual enterprises. According to the authors of the handbook, both approaches can be used simultaneously. However, they point to the dominant subjective approach due to the more important role of individual enterprises in shaping the economic effects and the greater importance of these data for public policy.

T. Nawrocki (Nawrocki, 2012, pp. 10 and next) proposes dividing the criteria for assessing innovativeness into generic groups, such as the resource potential of innovative activities, e.g. the staff employed in research and development centres, qualifications of the staff, opportunities for cooperation with other entities, equipment, technologies, financial resources or opportunities to obtain external financing, moreover, expenditure on innovative activities, e.g. expenditure on research and development, expenditure related to improving employees' qualifications, expenditure on investment activities, as well as results, including valuable results, e.g. the number of innovations launched or implemented on the market, number of patents, utility models, trademarks filed, value and share in total sales of new products, quality, e.g. the degree of novelty, level of complexity, diffusion possibilities or the scope of improvement of the qualitative characteristics of new solutions and time - when new solutions were introduced to use in comparison with the competition - before, at the same time, or after. Another important factor is the impact of innovative activities on the financial results of the company, e.g. the effect of implemented innovations on the change of sales revenues, expenses and financial results in the period short - to 1 year, average - up to 3 years and longer - approximately 5 years.

L. Białoń and D. Janczewska (Bialon, 2010, pp. 5 and next) base the measures on the basic components of the innovative potential, which include: the potential of science, technology and economy. This approach can also be used in a company, relating the concept of science to research, and technology to design aspects. According to the authors, learning potential can be a model for the assessment of staff knowledge in enterprises, and is defined by the size and quality of scientific knowledge and its degree of readiness for practical use, the number of research workers, engineers, technicians and support staff working in the field of research and development, level of qualifications and the degree of professional training, a network of research institutions, laboratories and other organizations, dealing solely or partially with research and development and material-technical base of science, including modern equipment, materials and progress in general. The distribution of human and material resources according to the branch of science and technology, the level of organization and management of research and development, the state of the scientific and information base and the state of computerization are also of great importance. Finally, important information can be obtained from the condition of international scientific ties, the scale and forms of 
international cooperation, the work efficiency of staff in the field of science and the level of financing, i.e. budget, sponsors or enterprises.

H. Salavou (Salavou et al., 2004, pp. 1091-1112) summarizes the most commonly used measures of organizational innovativeness, such as, the time needed to implement, application, i.e adaptation or non-application of innovation, level of expenditure on research and development, economic value of innovation, number of implemented innovations, as well as all subjective measures.

The European Innovation Scoreboard Table (https://ec.europa.eu/growth/sites/growth/files/ris201 9.pdf) published by the European Commission organizes selected indicators into four areas, i.e framework conditions, investing, innovative activity and impact.

In the sphere of framework conditions, in the category of human resources are such indicators as the number of new doctorates in the population aged 25-34 with higher education and lifelong learning; the attractive research systems category includes indicators, such as, international scientific publications, $10 \%$ of the most cited publications, as well as foreign $\mathrm{PhD}$ students; the innovation-friendly environment category includes two indicators, i.e. broadband networks and opportunity-based entrepreneurship.

There are two categories in the area of investing, i.e finance and support and corporate investments. In the category of finance and support two indicators were placed, i.e. expenditure on research and development in the public sector and expenditure on venture capital. In the corporate investment category there are three indicators, i.e. expenditure on research and development in the enterprise sector, expenditure on innovation not qualified as research and development as well as enterprises conducting training to develop or improve ICT (Information and Communication Technology) skills of their employees.

There are three categories in the area of innovative activity. In the category of innovators, three indicators referring to small and medium-sized enterprises - in short, SMEs, i.e. SMEs with product or process innovations, SMEs with marketing or organizational innovations as well as SMEs innovating on their own, were included. The linkage category includes three indicators, i.e. innovative SMEs collaborating with others, joint public-private publications as well as private co-financing of public $R \& D$ expenditure. In the category of intellectual property three indicators are included, i.e. PCT (PCT means Patent Cooperation Treaty) international patent application, trademark applications and application design.
There are two categories under impact. In the employment impact, category two indicators were placed, i.e. employment in knowledge-based activities and employment in fast-growing enterprises in innovative sectors. In the category of impact on sales, three indicators were included, i.e. the export of medium and highly advanced products, the export of knowledge-based services and the sale of market novelties and new innovative products.

The World Bank proposes to make the measurement of innovativeness on the basis of Knowledge Economy Indicatom (https://www. tandfonline.com/doi/full/10.1080/00220388.2018.15 54208), taking into account 12 measures divided into four areas, so each area contains three measures.

In the area of economic incentives and the institutional environment, the following measures are proposed: tariff and non-tariff barriers, the quality of regulation and the law.

The area of education and human resources includes measures: the adult literacy rate, secondary education and higher education.

In the area of information infrastructure there are the following indicators: the number of telephones per 1,000 inhabitants, the number of computers per 1,000 inhabitants and the number of Internet users per 1,000 inhabitants.

The area of the innovative system includes: the number of payments for licenses and patents per person in US dollars, the number of patents granted by the USPTO (USPTO means United States Patent and Trademark) per million inhabitants and the number of scientific technical publications per million inhabitants.

The aforementioned indicators should be used to assess the level of innovativeness in enterprises, including the assessment of such aspects of enterprise functioning as entrepreneurship, technological development or diversity. Taking into account the large number of proposals for measuring innovativeness, it is worth trying to limit the set of the applied criteria and create aggregated measures. The purpose of the analysis should be the basis for selecting a given method of assessing innovation.

\section{Conditions for the functioning of innovative enterprises}

External conditions affecting the innovation can be divided into these three groups: factors of direct influence, i.e. tax allowances, preferential loans, financing innovative projects, factors of indirect influence, i.e. education, science, research and implementation facilities, tax system, law, credit system, efficiency of central and local government administration, freedom of economic activity and sectoral factors, i.e intensity of competition in the 
sector, importance of general technological changes, internationalization of the sector.

On the other hand, the internal conditions include: creativity, entrepreneurship, leadership style, organizational culture, teamwork, staff quality and diversity, motivation system, the company's competitive situation, types of strategies, quality and nature of resources, detailed technological changes and structural and network connections (Romanowska, 2016, pp. 29-35)

Below I will present a detailed description of three of the above-mentioned internal conditions, which are entrepreneurship, technological development and diversity.

\section{Entrepreneurship}

Entrepreneurship is a way of acting, consisting in the tendency to undertake new, risky and unconventional ventures, and showing initiative in search and implementation. Therefore, it is an action aimed at development; it is innovative in nature. Entrepreneurship in the economic dimension consists in creating more effective organizational forms, introducing new production factors, conquering new sales and supply markets or introducing new products.

Entrepreneurship is an important determinant of economic changes taking place in the world. As a set of features and functions, it significantly affects the quality of the economy of the state, as well as institutions that are associations of states, such as the European Union. In modern economic conditions, it determines the company's competitive advantage, and its survival and success on the market. Finally, entrepreneurship, as an attribute of the human mind, determines the development of every person. Describing the means and the range of supporting entrepreneurship within the company's operations requires a defining of the role that entrepreneurship itself plays in social and economic life, both on a local and global scale.

The entrepreneurship of an economic entity depends on the quality of human capital. Innovative attitudes among the inhabitants and institutions focused on the multiplication of knowledge result in new ideas, solutions that forge a lasting competitive advantage and build entrepreneurship.

\section{Technological development}

Responsible entrepreneurship is reflected in the creation of responsible technologies. Since entrepreneurship is an economic and social value, an important effect of entrepreneurship of the organization's employees is their tendency to generate and implement new technological solutions. One of the manifestations of entrepreneurship is technological development, also defined above as the quality and nature of resources. On the other hand, generating innovation, in particular of a technological, product or process nature, is the basis for the entrepreneurial concept of enterprise competitiveness (Chyba, 2016, pp. 96-107). Technological strategy refers to the application of technology to achieve technological advantage and its maintenance, referring to the possession of the necessary competences. The innovativeness of a company is therefore related to its ability and motivation to implement the results of scientific research, research and development works, as well as the putting of new ideas and inventions into practice. It is connected with a constant search. In its research and development strategy, the company uses both its own research and development potential and external sources. The development strategies include: innovative strategy, technological strategy and research and development strategy (Janasz, 2016, pp. 29-35) The literature emphasizes the importance of the legitimacy of new technologies to enable their distribution. Social changes are inevitable due to the influence of new technologies. Three possible approaches of enterprises towards the emergence of innovative technologies are considered, i.e joining a new technology, exiting the market or accelerating the improvement of an existing technology, although this is a rare phenomenon (Fatula, 2018, pp. 9-26)

Technological development should take into account the objectives of sustainable development, not only economic but also social and environmental. Modern technologies use knowledge to base their development on entrepreneurial and innovative activities. Technologies are integrated into the created chain of values, which is essential in creating a competitive advantage of an economic entity. However, social aspects, including ecological ones, are increasingly emphasized in the value creation chain. Such issues should be taken into account already at the stage of research and development, and, therefore, should be responsible. It is essential that the aspects of responsibility in relation to entrepreneurship, innovativeness and the knowledge used are reflected in the organizational values. The study justifies the point of view presented in the thesis that responsible entrepreneurship and innovation are reflected in the creation of responsible technologies. Tools for assessing the mutual interaction between innovativeness and responsibility are also shown. Responsible technology should use the opportunities resulting from the assumptions of sustainable development and the role of corporate social responsibility (Chyba, 2016, pp. 96-107). 


\section{Diversity}

Diversity, also described above as teamwork or staff quality, is a value that is increasingly desired by modern enterprises. In many of them, diversity is not only one of the elements of the personnel policy, but also a long-term vision of development. At the same time, diversity is also a concern for some managers. There is still a strong conviction among a large part of the management - not only in Poland - that it is much easier and safer to manage homogeneous teams of people, and emphasizing civic attitudes in business is only a temporary fashion. Diversity is consciously overlooked in traditionally run companies, as it prevents the use of well-known, unified human resource management instruments.

The interest in diversity and its management is becoming more and more common, both in the world and in Poland. More and more often, the benefits of this are being promoted. One of them is certainly recognizing the team power of the employees in terms of diversity: uniting them, incorporating them into the common organizational culture and building commitment. As a result, diversity management can bring many different types of benefits to the company and perform various functions. One of them may be supporting employee innovativeness. A wise use of human resources in the development of innovativeness is of great and growing importance; in particular, it is important to prevent talent waste (Borkowska, 2010, p. 32)

\section{Eastern Poland}

According to the NUTS 2 delimitation, Eastern Poland comprises five voivodeships: Lubelskie, Podlaskie, Podkarpackie, Świętokrzyskie and Warmińsko-Mazurskie. The problem of their lower level of development, compared to the central and western part of the country, is primarily the problem of past historical events that affect the current low investment attractiveness and the level of socioeconomic development. The backwardness is also due to the unfavorable conditions that emerged with the transformation in Poland after 1989: the collapse of industry, which was often accompanied by the passivity of local elites waiting to solve this disadvantage by way of invisible market forces or by decision-makers from the capital. Apart from the syndromes typical for the less-developed regions, such as, a low level of civic activity or the lack of people's feeling that taking matters into their own hands is a chance to change the unfavorable financial situation, the problems of Eastern Poland were deepened by low commitment and aid, especially investment support, from the government administration, virtually during all thirty years of the transformation period. (Jozwik, Sagan, 2012, pp. 10 and next)

Another problem is the lack of investment in modern road and rail infrastructure in the eastern regions. The peripheral nature of the Eastern Poland region is considered to be another important factor negatively affecting the competitiveness of this part of Poland. In addition, this region moved after Poland's accession to the European Union to the external periphery, which was accompanied by an estrangement with Belarus, Russia and Ukraine. Eastern Poland is still relatively often stigmatized both from the outside and internally, which makes it difficult to make rational decisions about the right types of government intervention policy in this region, and often effectively scares away potential investors, tourists or students (Stefanski, 2011, pp. 96-97)

Therefore, both entrepreneurship, technological development, diversity, and other aspects of the functioning of innovative enterprises constitute a vital challenge to this day.

A few words about the main cities of Eastern Poland will shed light on the situation of this region.

Lublin has academic, educational, tourism, cultural and creative potential. This potential has been accumulated over many years, but the Lublin agglomeration is economically developing slower than the national average and definitely slower than the largest metropolises in the country (Warsaw, Poznań, Wrocław or Kraków). The city's economy is increasingly diversified and restructured, but still with too little share of modern industry and foreign investors in its structure. It is a city that will maintain its leading position in Eastern Poland and may reduce the gap with Western Poland and Warsaw, provided that access to development engines is improved - domestic access and external access through the city's internationalization mechanism. An important aspect of increasing the potential and competitive position of the city is stimulating changes in the traditional and social attitudes of the residents, institutions and enterprises, and supporting the construction of business ecosystems, e.g. the strong IT industry in Lublin. Lublin also needs greater government support to solve internal communication problems and to improve the quality of life of its inhabitants (Lublin's development strategy)

Białystok has a considerable economic potential, particularly given its academic and cultural institutions, and the city's focus on tourism. A significant factor stimulating the city's development in the next decade may be the inflow of very large funds from the European Union, external investors and the development of local enterprises. An additional development impulse for the city was greater transport accessibility, especially road connections with Warsaw. 
Kielce has economic potential and high rates of entrepreneurship but, at the same time, a low academic, cultural and creative potential. Despite this, it can become a center that develops its economy rapidly. Important factors for the development of Kielce are its favourable location being in central Poland and with relatively good access to the agglomerations of Warsaw and Kraków, the entrepreneurial potential of the city's inhabitants and the expected inflow of large aid funds from the EU (Kielce development strategy).

Olsztyn is a promising academic, cultural and tourism center. The weakness of the city is its low economic potential. Moreover, it is a city with a low population potential. Olsztyn is the city of Eastern Poland which, per capita, receives the highest support from EU funds, which enables it to increase the quality of life of its inhabitants and facilitates competition for external capital resources, students and creative classes. Despite its location in a very attractive region for tourists, Olsztyn does not use these opportunities to a sufficient extent (Olsztyn development strategy).

Rzeszów is a city with the lowest potential among the capital cities of Eastern Poland's regions. It is the capital of one of the two poorest regions in Poland and an agglomeration with a very low GDP per capita. The city, after a period of extensive growth resulting from the establishment of a university, the expansion of the airport, employment growth in the Aviation Valley and the transfer of labour from rural areas to Rzeszów, as well as a very effective absorption of EU funds, has failed to significantly increase its total potential. It remains a very weak academic center and an even weaker center of cultural creation. The city should significantly diversify its economy and invest in the potential of culture. Another significant problem of Rzeszów is its peripheral location and poor links with Warsaw. Rzeszów has too little potential to influence the surroundings of southeastern Poland and may be marginalized by the much stronger centers of Kraków and Lublin (Development strategy of Rzeszów).

From a historical perspective, the voivodeships of Eastern Poland belonged to low-urbanized, poorly industrialized, underinvested and less developed areas in terms of infrastructure, and consequently with a lower level of socio-economic development compared to the rest of the country.

Culture is neither the only nor the most important factor influencing the development of Eastern Poland, and the functioning of this macroregion, and the converse obtains. When considering the influence of cultural factors on this process, they can be viewed from various points of reference. They may result from a specific system of values of a general cultural nature, as well as refer to particular spheres of community life in which they play a local role. Considering the conditions for development it is significant to make a distinction between the universal and regional level. It seems that the universal values determine, to a certain extent, the shape and, partially, the character of this process. It is worth noting that they require increased attention, which is necessary for a continuous analysis of the relationship between the world of culture and the different elements that determine development. It may be more difficult to identify subsequent layers of culture that affect social change and development. Some of the values and norms are not always implemented by the citizens of a given region, they remain only a declaration, while others can be presented in action. Undoubtedly, it can be said that there are some common elements that cause similar trends in the region of Eastern Poland.

Entrepreneurship in the region of Eastern Poland is characterized by a lower potential compared to other regions in the country, which is the result of the general economic situation and the condition of the economic and technical infrastructure of this region. The diagnosis of the socio-economic situation of Eastern Poland shows that it is an area with a low level of development compared to the rest of the country, which does not create favourable conditions for the development of entrepreneurship. The Eastern Poland region exhibits features that make it peripheral in relation to national and European centers of economic activity, mainly due to the low level of affluence, expressed in a low level of GDP per capita, a low level of spatial, social and economic cohesion, and an ineffective structure of the economy with a predominance of traditional agriculture and a relatively low level of entrepreneurship development and a low level of competitiveness and innovation of enterprises. The potential of growth centers stimulating development, including clearly developed urban agglomerations with well-developed metropolitan functions, is also insufficient. There is also an underdevelopment of the infrastructure of higher education and limited links between science and economy, as well as a low level of development of the technical infrastructure, especially ICT and transport, and inefficient communication connections, which determine the limited accessibility of Eastern Poland.

The above description of the situation in Eastern Poland shows that this is a region with unfavorable conditions for the development of entrepreneurship, due to an insufficiently developed economic base. In almost all aspects, aside from internal security, the voivodeships of Eastern Poland perform worse than other parts of the country. The region suffers from deficiencies in the development of communication, economic, human resources and local market 
infrastructure, which are important factors for the development of entrepreneurship.

When looking for prospects for the development of entrepreneurship in the region of Eastern Poland, one should be aware that the development of entrepreneurship is conditioned by macro- and microeconomic factors. There is a close relationship between the level of economic development of a given region and the development of entrepreneurship. After all, the modern economy is shaped by three interrelated processes: globalization, competition and innovation. Permanent competitive advantage is gained by those regions where there are enterprises capable of creating and absorbing innovation.

\section{Summary}

The determinants of enterprise innovation processes characterized in the above article were based on the theoretical foundations of innovation contained in management sciences. It was assumed that the innovation process begins even before the start of research in the enterprise, at the stage of creating an idea, and ends with the implementation of innovation and its dissemination. The solutions do not necessarily have to be produced from the beginning in the enterprise. Modern enterprises operating in a cooperation network and in cooperation with the sphere of science, manifested in the sharing of innovative knowledge, is considered one of the most sought forms of cooperation. Innovations are the result of complex technical, social, economic, legal, cultural and organizational processes, the course of which can be shaped through the effective management of a company and its relations with the environment.

\section{References}

Bialon, L. (2010). Zarządzanie działalnością innowacyjną. [Managing innovation activities]. Warszawa: Placet.

Borkowska, S. (2010). Rola ZZL w kreowaniu innowacyjności. [ZZL's role in creating innovation]. Warszawa: Wyd. C. H. Beck.

Chyba, Z. (2016). Pozyskiwanie technologii a kreowanie przedsiębiorczości technologicznej. [Acquiring technology and creating technological entrepreneurship]. Ekonomika i Organizacja Przedsiębiorstwa (4), 96-107.

Fatula, D. (2018). Wybrane zagadnienia zarządzania rozwojem organizacji. [Selected considerations for managing organizational development]. Kraków: Oficyna Wydawnicza AFM.

Janasz, K. (2016). Dylematy wyboru strategii rozwojowych przedsiębiorstw przemysłowych. [Dilemmas for choosing industrial business development strategies]. Przegląd Organizacji, (10) 2016, 29-35.
Jozwik, B., Sagan, M. (2012). Rozwój Polski Wschodniej - ograniczenia $i$ wyzwania. [The development of Eastern Poland - limitations and challenges]. Warszawa: Difin.

Nawrocki, T. (2012). Innowacyjność produktowa przedsiębiorstw. [Enterprise Product Innovation]. Warszawa: CeDeWu.

Romanowska, M. (2016). Determinanty innowacyjności polskich przedsiębiorstw. [Determinants of the innovation of Polish enterprises]. Przegląd Organizacji (2), 29-35.

Salavou, H., Baltas, G., Lioukas, S. (2004). Organisational innovation in SMEs: The importance of strategic orientation and competitive structure. European Journal of Marketing, (38) (9/10), 1091$-1112$.

Stefanski, M. (2011). Strategiczna problematyka rozwoju Regionu Lubelskiego. [Strategic development of the Lublin Region]. Lublin: Innovatio Press, 96-97.

https://ec.europa.eu/eurostat/web/products-manuals-and-guidelines/-/OSLO?inheritRedirect=true.

https://ec.europa.eu/growth/sites/growth/files/ris201 9.pdf.

https://www.tandfonline.com/doi/full/10.1080/00220 388.2018.1554208.

Strategia rozwoju Bialegostoku. [Strategy for the development of Bialystok]. Retrieved from https://www.bialystok.pl/pl/dla_biznesu/rozwoj_m iasta/.

Strategia rozwoju Kielc. [Kielce development strategy]. Retrieved from http://www.um.kielce.pl/ strategia/.

Strategia rozwoju Lublina. [Lublin development strategy]. Retrieved from https://lublin.eu/biznesi-nauka/strategia/s2030/.

Strategia rozwoju Olsztyna. [Olsztyn development strategy]. Retrieved from https://olsztyn.eu/ gospodarka/dokumenty-strategiczne/strategiarozwoju-miasta.html.

Strategia rozwoju Rzeszowa. [Rzeszow develipment strategy]. Retrieved from s.bip.erzeszow.pl > file > 0_strategia rozwoju ... . 